\title{
Comunicação
}

[Communication $]$

\section{Sensibilidade da PCR na amplificação do DNA bovino em diluição seriada e mistura de amostra macho e fêmea}

[Sensitivity of PCR to amplify sex-specific bovine DNA in diluted samples]

\author{
A.S. $C r u z^{1,2}$, D.C. Silva ${ }^{1}$, E.O.A. Costa ${ }^{1}$, D.M. Silva ${ }^{1}$, D.A. Abreu ${ }^{1}$, A.D. Cruz ${ }^{1 *}$ \\ ${ }^{1}$ N. P. Replicon, D. de Biologia, Pontifícia Universidade Católica de Goiás \\ Rua 235, no 40 - S. Universitário \\ 74605-010 - Goiânia, GO \\ ${ }^{2}$ Aluno de pós-graduação - Instituto de Ciências Biológicas 4 - Goiânia, GO
}

A ultrassonografia e a PCR embrionária in vitro são métodos propostos com relativa eficiência para a determinação do sexo fetal em bovinos (Martinhago et al., 2006; Tellam et al., 2009). No entanto, ainda há restrições e limitações de ordem técnica, de custeio e de segurança animal, as quais provocam uma variação substancial nos resultados. Assim, as limitações mencionadas diminuem a eficiência das técnicas na prática rotineira, sobretudo no manejo de grandes rebanhos (Lopes da Costa et al., 2002). Em humanos, é possível amplificar regiões cromossômicas fetais a partir de DNA extraído do plasma materno por PCR (Lo et al., 1997). Lo et al. (1998) relataram que, para cada cópia de DNA fetal extraído do plasma materno, foram obtidas, a partir da quinta semana de gestação, até 99 cópias de DNA da mãe. Atualmente, a amplificação de regiões alossomo-específicas por PCR tem sido usada como uma estratégia de determinação precoce do sexo fetal, com resultados excelentes devido à alta sensibilidade e especificidade do método (Carvalhais et al., 2005).

O objetivo geral deste trabalho foi avaliar a capacidade de amplificação e discriminação de DNA bovino em diluição seriada por PCR. Adicionalmente, uma mistura do DNA genômico de macho e fêmea bovinos, em diferentes proporções, foi preparada com o objetivo de se estabelecer a sensibilidade da PCR para discriminar em uma amostra a presença de DNA masculino, simulando as condições presentes no plasma de vacas prenhes.

Dos animais doadores foram obtidas duas amostras de sangue periférico, sendo uma amostra de um touro e uma amostra de uma novilha, não prenha, da raça Jersey. $O$ sangue total foi coletado por punção da veia caudal com seringas contendo heparina. As amostras foram processadas, separando-se o plasma do componente celular por centrifugação (1000rpm/ 10min). O DNA total foi isolado e purificado usando-se o kit comercial Illustra Blood GenomicPrep Mini Spin ${ }^{\circledR}$ (GE Healthcare, UK), seguindo as instruções do fabricante. A quantificação do DNA foi realizada em um fluorômetro - GeneQuant Pro ${ }^{\circledR}$ (Amersham Biosciences, EUA), conforme instrução do fabricante.

Após a extração e a quantificação do DNA bovino, as amostras foram diluídas para a concentração inicial de $40 \mathrm{ng} / \mu \mathrm{L}$ de DNA, usadas como controle (AC) para amplificação por PCR. As ACs foram diluídas em série quatro vezes, partindo de um fator de diluição igual a 1000 (amostras 1 a 4). Subsequentemente, foram realizados dois passos de diluição com fator de diluição de 100 (amostras 5 e 6). Ao final da diluição seriada, foi obtida a proporção de uma parte do DNA extraído para $10^{16}$ partes de água

Recebido em 2 de abril de 2010

Aceito em 8 de junho de 2011

*Autor para correspondência (corresponding author)

E-mail: acruz@pucgoias.edu.br 
mili-Q. De cada amostra foram utilizados $10 \mu \mathrm{L}$ da solução para a PCR. Portanto, a quantidade total de DNA inicial no sistema de amplificação por PCR foi de 400ng de DNA (Tab. 1).

Todo o procedimento foi realizado em triplicata. A PCR foi preparada para um volume final de $25 \mu \mathrm{L}$. Para as amostras testadas, foram usados $10 \mu \mathrm{L}$ de solução aquosa contendo DNA bovino. As condições de PCR incluíram 0,150 pmoles de cada conjunto de primers, $5 \mu \mathrm{L}$ de tampão de PCR Gold STR ${ }^{\circledR}$ (Promega Corporation, EUA), $50 \mathrm{mM}$ de cloreto de magnésio e $0,5 \mu \mathrm{L}$ de Taq DNA polimerase $(5 \mathrm{U} / \mu \mathrm{L})$. $\mathrm{O}$ protocolo de termociclagem utilizado continha um passo inicial de desnaturação a $94^{\circ} \mathrm{C}$ por $5 \mathrm{~min}, 40$ ciclos a $94^{\circ} \mathrm{C}$ por $1 \mathrm{~min}$ de desnaturação, anelamento a $58^{\circ} \mathrm{C}$ por 30 seg e extensão a $72^{\circ} \mathrm{C}$ por $1 \mathrm{~min}$, e de extensão final de $7 \mathrm{~min}$ a $72^{\circ} \mathrm{C}$.

Tabela 1. Quantificação e diluição de DNA isolado de sangue de bovinos, usado para estimar a sensibilidade da PCR para amplificação de regiões cromossômicas autossômicas e alossômicas de bovinos

\begin{tabular}{ccc}
\hline Amostra & Diluições $^{\text {DNA } / \text { água }}$ & Quantidade de DNA* $(\mathrm{ng})$ \\
\hline $\mathrm{C}$ & $1: \overline{10}^{3}$ & 400 \\
1 & $1: 10^{6}$ & $4 \times 10^{-1}$ \\
2 & $1: 10^{9}$ & $4 \times 10^{-4 *}$ \\
3 & $1: 10^{12}$ & $4 \times 10^{-7} *$ \\
4 & $1: 10^{14}$ & $4 \times 10^{-10 *}$ \\
5 & $1: 10^{16}$ & $4 \times 10^{-12 *}$ \\
6 & $4 \times 10^{-14 *}$ \\
\hline
\end{tabular}

C: amostra-controle; *: Estimada matematicamente, pois as amostras foram diluídas a ponto de ultrapassar o limite mínimo de detecção de DNA pelo método fluorimétrico.

O conjunto de primers descritos por Resende et al. (2008) foi usado para a amplificação do genoma bovino. Um conjunto (5' CCTCCCCTTGTTCAAACG CCCGGAATCATT 3' e 5'TGCTTGACTGCAGGGACCGAGAGGTTTGGG 3') foi desenhado para detectar uma sequência de $210 \mathrm{pb}$ localizada no cromossomo $\mathrm{Y}$, e outro conjunto (5' AGGTCGCGAGATTGGTCGCTAGGTCATGCA 3' e 5' AAGACCTCGAGAGACCCTCTTCAACACGT 3') foi preparado para identificar uma sequência autossômica de 280pb localizada no cromossomo 1.

A amostra de DNA extraída do sangue do macho foi misturada à amostra de DNA extraída da fêmea. O sistema, assim preparado, permitiu a determinação da sensibilidade da PCR para amplificar a região Y-específica, simulando as condições do plasma de vacas prenhes de conceptos machos. As amostras foram ajustadas percentualmente, e suas proporções estão descritas na Tab. 2.

Tabela 2. Mistura das amostras de DNA bovino de fêmea e macho

\begin{tabular}{|c|c|c|c|c|}
\hline Amostra & Mistura & Parte autossômica & $\begin{array}{l}\text { Parte Y- } \\
\text { específico }\end{array}$ & Proporção A:Y \\
\hline $\mathrm{C}+\hat{O}$ & Macho & 2 & 1 & $2: 1$ \\
\hline $\mathrm{C}+q$ & Fêmea & 2 & 0 & $2: 0$ \\
\hline 1 & $50 \% \bigcirc 50 \% \widehat{ }$ & 2 & 0,5 & $4: 1$ \\
\hline 2 & $80 \%$ 우 $20 \% \widehat{\jmath}$ & 2 & 0,2 & $10: 1$ \\
\hline 3 & $95 \%$ 우유 & 2 & 0,05 & $40: 1$ \\
\hline 4 & $99 \%$ 우 $1 \%$ 중 & 2 & 0,01 & $200: 1$ \\
\hline 5 & $99,9 \%$ & 2 & 0,001 & 2000:1 \\
\hline
\end{tabular}

$\mathrm{C}+\delta^{\lambda}$ : controle de macho; $\mathrm{C}+$ + : controle de fêmea; 1 a 5 amostras misturadas de fêmea e macho.

A amplificação das amostras diluídas de fêmea foi possível até uma diluição de $1 \times 10^{14}\left({ }^{\mathrm{DNA}} / \mathrm{ÁGUA}\right)$ e concentração estimada em $4 \times 10^{-12}$ ng de DNA.
Não foi observada a amplificação do fragmento autossômico de DNA esperado para a amostra da canaleta 6, demonstrado na Fig. 1I. A partir da 
diluição seriada das amostras, foi possível identificar a concentração mínima de DNA do macho que ainda pôde ser amplificado. A amplificação de $280 \mathrm{pb}$ indicava a região autossômica, e 210pb a região específica do cromossomo Y. Na Fig. 1II, mostra-se a amplificação por PCR da região autossômica, identificável nas amostras A, 1, 2, 3, 4 e 5, o que equivale a uma quantidade de DNA de $4 \times 10^{2}$ a $4 \times 10^{-12}$ ng de DNA. A amplificação da região Yespecífica foi possível até a amostra 2, correspondente a $4 \times 10^{-4} \mathrm{ng}$ de DNA. A amostra da canaleta 6 não amplificou. Um controle negativo de amplificação foi incluído nas reações.
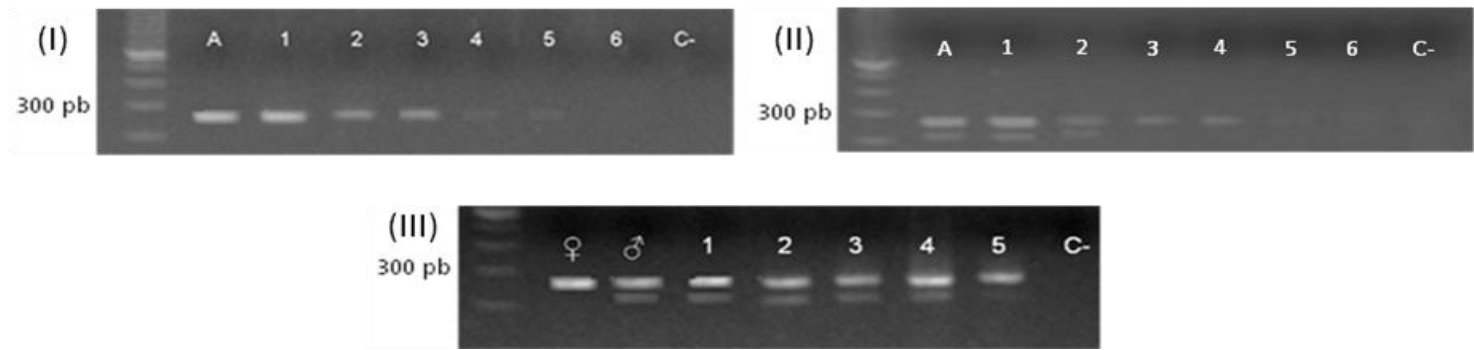

Figura 1. Amplificações de amostras em diluição seriada de sangue bovino de macho (I), fêmea (II). (III) amostras misturadas $\hat{\sigma}$ e ${ }^{\circ}$. Em I e II, A: amostra normal (400ng de DNA), 1 (4x $\left.10^{-1} \mathrm{ng} / \mathrm{DNA}\right), 2\left(4 \times 10^{-}\right.$

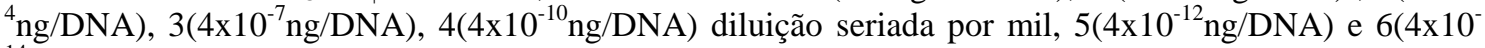
$\left.{ }^{14} \mathrm{ng} / \mathrm{DNA}\right)$ diluição seriada por cem, C- controle negativo da reação. Em III: amostras misturadas, +

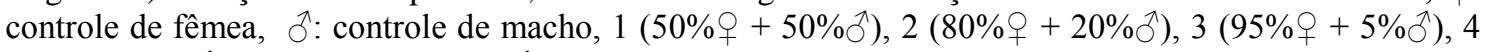
$(99 \%$ ㅇ $+1 \%$ đ), $5(99,9 \%$ 우 $+0,1 \%$ đ $)$ e C- controle negativo

A amplificação por PCR das amostras da diluição seriada em macho e fêmea comportou-se de forma semelhante. Assim, foi possível inferir que a sensibilidade de amplificação da região autossômica de bovinos correu até a concentração de $4 \times 10^{-12}$ de DNA por amostra, representada nas Fig. 1I e II. Como a mistura das amostras foi oriunda de material extraído de sangue total de macho e fêmea, as proporções de genomas Y-específico e autossômico estão distribuídas na Tab. 2.

A amplificação da região Y-específico foi possível até a quantidade de $4 \times 10^{-4} \mathrm{ng} / \mu \mathrm{L}$ de DNA. A determinação cromossômica do sexo em bovinos é feita por um sistema simples, sendo os machos heterogaméticos. Isto justifica a observação de a variação na amplificação entre as regiões autossômicas e alossômicas ser 2:1, ou seja, existem duas partes de região autossômica para uma parte de Y-específico. Na amostra 5 da Fig. 1III, foi observada a amplificação apenas do DNA de 9 . Assim, este limite indica a sensibilidade da PCR para discriminar o DNA do $\widehat{\jmath}$ e da $\bigcirc$ (200:1) no presente estudo.
Nesse sentido, os resultados do presente ensaio demonstraram que a amplificação de amostras misturadas contendo regiões genômicas Yespecífico de macho diluída em amostra de fêmea é possível. Os resultados foram seguramente positivos até a mistura de 200 partes autossômicas para 1 parte $\mathrm{Y}$-específico, indicando, assim, a sensibilidade do método em bovinos. Os resultados do presente estudo sugerem que a amplificação da região $\mathrm{Y}$ específico em amostra de sangue de vacas prenhes pode ser convenientemente usada como ferramenta de sexagem fetal. Encontram-se em fase de conclusão experimentos laboratoriais de sexagem fetal por PCR a partir do DNA extraído de vacas prenhes, em diferentes estágios gestacionais, pelo grupo deste estudo, com taxas de concordância de $100 \%$ (dados não publicados).

Palavras-chave: PCR, DNA bovino, determinação sexual, sensibilidade 


\begin{abstract}
A mixture of bovine DNA from a male and a female Jersey (Bos taurus taurus) bred in different proportions was used to determine the sensitivity of PCR to amplify and discriminate the bovine DNA samples. Samples were obtained from the peripheral blood of a bull and a heifer and DNA was isolated using a commercial kit for extraction and purification of nucleic acids. Two primers sets were designed to flank genomic regions: one autosomal and one Y-specific. DNA samples were diluted in water to a final concentration of $4 \times 10^{-14} \mathrm{ng}$. The results showed positive amplification of the samples diluted to a concentration of $4 \times 10^{-10} \mathrm{ng}$ and $4 \times 10^{-4} \mathrm{ng}$ for the autosomal and $Y$-specific regions, respectively. PCR was

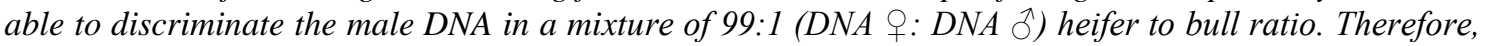
the PCR was successful in amplifying the bovine genome in samples containing low concentrations of DNA. Thus, PCR can be used as a sensitive and efficient tool to determine the sex of the fetus in pregnant cows, helping to promote correct and efficient animal management, sex selection, and breeding in commercial herds.
\end{abstract}

Keywords: PCR, bovine DNA, sex determination, sensitivity

\section{AGRADECIMENTOS}

Os autores agradecem ao Departamento de Zootecnia da PUC Goiás, pela doação das amostras de sangue dos animais.

\section{REFERÊNCIAS BIBLIOGRÁFICAS}

CARVALHAIS, I.; PIMENTA, J.; MARQUES, C.C. et al. Implementação de um método simples e preciso para sexagem de embriões bovinos. Cienc. Vet., v.3, p.121-124, 2005.

LO, Y.M.; CORBERTTA, N.; CHAMBERLAIN, P.F. et al. Presence of fetal DNA in maternal plasma and serum. Lancet, v.16, p.350-359, 1997.

LO, Y.M.; TEIN, M.S.; LAU, T.K. et al. Quantitative analysis of fetal DNA in maternal plasma and serum: implications for noninvasive prenatal diagnosis. Am. J. Hum. Genet., v.62, p.768-775, 1998.
LOPES DA COSTA, L.; CHAGAS E SILVA, J.; DINIZ, P.; CIDADÃO, R. Preliminary report on sexing bovine preimplantation embryos under the conditions of Portugal. Rev. Port. Cienc. Vet., v.97, p.95-98, 2002.

MARTINHAGO, C.D.; OLIVEIRA, M.R.; TOMITÃO, M.C. et al. Determinação precoce do sexo fetal pela análise do DNA no plasma materno. Rev. Bras. Ginecol. Obstet., v.28, p.190-194, 2006.

RESENDE, M.V.; MOREIRA-FILHO, C.A.; LEAL, C.L.V. et al. Falha na sexagem por inibição do desenvolvimento de embriões bovinos produzidos in vitro com anticorpos anti H-Y. Arq. Bras. Med. Vet. Zootec. v.60, p.594599, 2008.

TELLAM, R.L.; LEMAY, D.G.; TASSELL, C.P.V. et al. Unlocking the bovine genome. BMC Genomics, v.24, p.193-197, 2009. 